\title{
ВСЕМИРНАЯ ПРОДОВОЛЬСТВЕННАЯ БЕЗОПАСНОСТЬ, КАК АСПЕКТ МЕЖДУНАРОДНО-ПРАВОГО СОТРУДНИЧЕСТВА ГОСУДАРСТВ
}

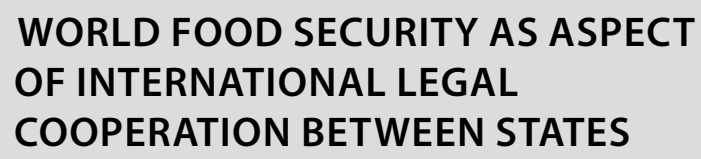

WORLD FOOD SECURITY AS ASPECT

OF INTERNATIONAL LEGAL COOPERATION BETWEEN STATES

D. Amirov

Summary. The article examines the approaches of states through the prism of cooperation within the framework of international organizations. It is no secret that the food security situation in the world today raises serious concerns. The emerging trend will inevitably lead to an increase in the number of hungry people around the world. The solution to the problem of food security is impossible without the active participation of all members of the world community, and in this regard, the need to strengthen international cooperation between states is becoming more urgent than ever.

Keywords: international law, international cooperation, food security, international organization, FA0, WTO.

\author{
Амиров Дамир Камилевич \\ Аспирант, Казанский (Приволжский) федеральный \\ университет \\ Amirov@mail.ru
}

Аннотачия. В статье рассматриваются подходы государств через призму сотрудничества в рамках международных организациях. Не секрет, что ситуация с продовольственной безопасностью в мире на сегодняшний день вызывает серьезные опасения. Складывающаяся тенденция неизбежно приведет к росту голодающих по всему миру. Решение проблемы продовольственной безопасности невозможно без активного участия всех членов мирового сообщества и в этой связи необходимость усиления международного сотрудничества государств как никогда приобретает актуальность.

Ключевые слова: международное право, международное сотрудничество, продовольственная безопасность, международная организация, ФАО, BTO.

изводимой продукции. Использование антибиотиков, гормональных препаратов и других с недостаточно изученными свойствами веществ, таит в себе абсолютно не предусмотренные риски для жизни и здоровья человека [2]. Несмотря на это, главным и основным источником употребления в пищу были и остаются сельскохозяйственные продукты, в связи с чем улучшение их качества с точки зрения продовольственной безопасности является проблемой глобального характера [3]. В этой связи, принимаемые в международных организациях правовые акты, в той или иной степени затрагивают проблему глобальной продовольственной безопасности [4].

Вне всякого сомнения, проблема продовольственной безопасности на глобальном уровне несет в себе гуманитарные угрозы, сохраняя тем самым за собой лидерство в общем числе глобальных угроз вызывающих обеспокоенность у международного сообщества, однако высказываться о скорейшем решении проблемы в контексте жизни или смерти всего человечества, на наш взгляд является не однозначным и преждевременным [2].

Если говорить о продовольственной безопасности через призму отношений и взаимодействия государств, то конечно же речь идет о международной продоволь- 
ственной безопасности. В этом случае, по нашему мнению, неоднозначное определение международной продовольственной безопасности дает Ю.А. Валетова. В своем работе, «Международно-правовое обеспечение продовольственной безопасности» автор определяет данное понятие как состояние защищенности международного сообщества, но не мирового сообщества и человечества, от угроз, связанных с ограничением доступа как физического, так и экономического плана к безопасному продовольствию [2].

Конечно, в большинстве случаев в правотворческой деятельности субъектов международного права, понятия «международное сообщество» и «мировое сообщество» употребляются как синонимы, однако на доктринальном уровне они не всегда используются и понимаются одинаково [5], а «человечество», которое достаточно часто употребляется в международно-правовых актах [6], представляется как объект безопасности, либо выражается общая заинтересованность всего человечества какой-либо проблемой.

Таким образом, с точки зрения направленности угрозы продовольственной безопасности, конечным потерпевшим от её последствий будет не государства и международные организации, а совокупность людей, живущих на планете земля, как народы, нации, олицетворяющие человечество. В этой связи хочется обратить внимание на мнение профессора кафедры международных экономических отношений и внешнеэкономических связей МГИМО Л.С. Ревенко предлагающую понимать под продовольственной безопасностью способность всего человеческого сообщества... удовлетворять потребности населения в продуктах питания в необходимых объемах, ассортименте и качестве за счет обеспечения ресурсами и создания соответствующих экономических условий [7].

Изначально желание сотрудничества у государств в области проблем, связанных с продовольственной безопасностью, возникло в период Второй мировой войны и ознаменовано это событие было в США на Международной конференции по вопросам продовольствия и сельского хозяйства в Хот-Спрингсе в 1943 году. В результате работы Международной конференции было принято решение об учреждении FAO [8]. Одной из основных целей организации является обеспечение продовольственной безопасности в мире. В последствии организация приобрела специализированный статус ООН по вопросам питания, продовольствия и сельского хозяйства. Сегодня в состав организации входят 194 государства-члена, два ассоциированных члена и одна организация-член - Европейский союз [9]. В рамках организации были приняты ряд важнейших международно-правовых актов, которые способствуют укре- плению продовольственной безопасности в мире. Так, например, в результате межведомственного сотрудничества со стороны FAO, на базе UNEP [10] в 1998 году была принята Роттердамская конвенция о процедуре предварительного обоснованного согласия в отношении отдельных опасных химических веществ и пестицидов в международной торговле. Положения данной конвенции предоставляют возможность государствам самим принимать решения, какие пестициды или опасные химические вещества они хотят получить, а какие отклонить по причине отсутствия возможности безопасного обращения. Подтверждает факт важности конвенции и то обстоятельство, что в 2003 году Роттердамская конвенция была преобразована в европейский регламент [11].

Обладая огромным опытом и накопленным информационным потенциалом, который можно оценить как источник знаний, FAO лидирует в деле налаживания международного сотрудничества в целях обеспечения глобальной продовольственной безопасности, организация является обеспечительным механизмом равноправного общения стран участниц и выступает в качестве независимого арбитра при проведении дискуссий и обсуждений различного рода вопросов связанных с проблемами глобального продовольственного кризиса.

Сегодня, в век изобилия и развития общества потребления, многие люди не только развитых но и развивающихся стран, даже и представить себе не смогут ситуацию, при которой могут иссякнуть запасы отдельных видов сельскохозяйственных культур, например таких как сахар, кофе, оливковое масло и много другой не менее важной сельскохозяйственной продукции.

Осуществляя сотрудничество с международными организациями учрежденными по инициативе самой $\mathrm{FAO}$, последняя может координировать деятельность таких учреждений, а также определять их политику деятельности. Прежде всего это связано не с идеей своего монополистического влияния на международной арене, а сцелью поддержания стабильности на соответствующих рынках международной торговли сельскохозяйственной продукции, которая может подвегнуться опасности, например из-за резкго колебания цен в случае перепроизводства или дефицита.

Таким образом, благодаря проводимой политики «мягкого сдерживания» в результате влияния на производителей и потребителей сельскохозяйственной продукции, FAO осуществляет важнейшую регулятивную функцию в столь стратегическо-важной отрасли мирового производства сельскохозяйственного продовольствия. 
Важную роль в деле обеспечения продовольственной безопасности осуществляет созданный на 18 сессии Конференции FAO резолюцией 21/75 в качестве комитета Совета, Комитет по всемирной продовольственной безопасности.

Комитет является наиболее широкой международной и межправительственной платформой для осуществления совместной скоординированной работы широкого круга убежденных единомышленников, направленной на поддержку регулируемых странами процессов по обеспечению продовольственной безопасности...[12]

Одной из главных задач Комитета по всемирной продовольственной безопасности заключается в том, чтобы активно следить за осуществлением Плана действий, принятого на Всемирном продовольственном саммите 1996 года. Хотя страны принимают меры для решения проблемы отсутствия продовольственной безопасности, представляемые конкретные программы не всегда позволяют давать количественный отчет о достигнутом прогрессе на пути к реализации целей Плана действий, принятого на Всемирном продовольственном саммите 1996 года. Комитету надлежит помогать странам и регионам в соответствующих случаях в рассмотрении вопросов о том, достигаются ли поставленные цели и как быстрее и эффективнее сократить масштабы проблем отсутствия продовольственной безопасности...[12]

Как значимый показатель международно-правового сотрудничества государств по проблеме продовольственной безопасности, является участие стран в международных конференциях, непосредственно затрагивающих этот вопрос. История международного взаимодействия знает множество примеров таких событий: Международная конференция по вопросам сельского хозяйства и землепользования 1999, Международная конференция о роли биотехнологий использовании и охране сельскохозяйственных генетических ресурсов 2005, Международная конференция «Мировая продовольственная безопасность и вызовы, связанные с изменениями климата и биоэнергетикой 2008, Всемирный саммит по продовольственной безопасности 2009.

Это не весь перечень мероприятий, проводимых его участниками, а лишь малая его часть. В качестве инструментария, практика таких встреч совместной работы представителей различных стран, озабоченных проблемой продовольственной безопасности, оказывает позитивное влияние на внутреннюю политику правительства отдельных государств, но тем не менее, общему процессу решения столь сложной проблемы мешают как внутренние противоречия их участников, так и отсутствие императивных норм, находящих свое отражение в резолюциях международных организаций, например, таких как FAO.

Обозначив предмет нашего исследования в теоретическом смысле обрамляя его рамками продовольственной безопасности на глобальном, международном уровне, нам бы от части, все же хотелось затронуть вопрос национальной продовольственной безопасности, поскольку на наш взгляд эти, казалось бы, на первый взгляд два разных направления, очень взаимосвязаны.

Не секрет, что, представляя себе то или иное государство необходимо абстрагироваться. Рассуждая о государственном сотрудничестве, мы понимаем, что все делается руками конкретных людей. В любых производственных, экономических, политических, социальных и других процессах в эпицентре событий стоят люди, исключением лишь, пожалуй, могут быть какие-либо природные катаклизмы, и те, иной раз связывают с вмешательством человека в природу.

К примеру, причиной порождающую проблему продовольственной безопасности на глобальном уровне, может быть засуха или наводнение на большей части целого континента и это проблема гуманитарного характера, которая в той или иной степени может коснуться любого региона мира где есть большие территории земель, задействованные в производстве сельскохозяйственной продукции. С другой стороны, продолжается процесс либерализации норм и правил международной торговли, который тоже может ударить по продовольственной безопасности, но уже отдельных стран. По этой причине, нам совершенно очевидны опасения некоторых государств, которые боятся полностью попасть в зависимость от импорта сельскохозяйственных товаров. Также очевидным для нас является ответ на вопрос, кто или кому выгодна такая либерализация норм и правил международной торговли, завуалированная под свободные демократические процессы развития. Здесь, в основе стоят прежде всего политические и экономические интересы развитых стран, а не идеи гуманитарного характера, поскольку ведь и сама идея гуманитарной помощи, тоже может негативным образом сказаться на адресате-получателе такой помощи...

Сразу заметим, что речь идет о проблемах развивающихся стран, так как вряд ли можно говорить, что экономически развитые государства будучи основными производителями и экспортёрами сельскохозяйственной продукции, из-за принятия обязательств по либерализации торговли такими товарами подвергают 
каким-либо рискам внутреннюю продовольственную безопасность.

Яркий пример угрозы ослабления продовольственной безопасности отдельно взятой страны, можно увидеть во взаимоотношениях в рамках Всемирной торговой организации (ВТО). При обязанности открывать «двери» национальных рынков для импортной сельскохозяйственной продукции, для развивающихся государств участников ВТО возникает внешнее противоречие между интересами наднационального характера идущего вразрез с концепцией национальной продовольственной безопасностью. Конечно, продовольственная безопасность упоминается в нормативных актах ВТО, например в самой преамбуле Соглашения, в которой говорится о справедливом распределении обязательств по программе реформы между всеми членами организации по вопросам не касающихся торговли и продовольственной безопасности. Однако данное положение несет в себе исключительно декларативную нагрузку, так как на сегодняшний день отсутствует действенный механизм контроля за соблюдением справедливого распределения обязательств государствами-участниками [13].

Также, в контексте угроз национальной продовольственной безопасности хотелось бы обратить внимание на международно-правовой акт универсального характера. Так, например, благие начала Конвенции ООН об оказании продовольственной помощи 1999 года, ставят в обязанность странам донорам, каждый год оказывать помощь развивающимся странам в виде поставок зерна в установленном минимальном объеме, а также финансирование для закупки зерна в виде кредитования. К слову, в список стран-доноров входят такие государства как США, Канада, государства - члены ЕС, Швейцария и другие развитые страны [14]. Тем самым, поддерживаются собственные производители сельскохозяйственной продукции стран-доноров, их граждане обеспечиваются рабочими местами, по сути, создается существенная налогооблагаемая база целой отрасли экономики внутри своей собственной страны, а выделение кредитов на закупки зерна, это на наш взгляд своего рода валютная экспансия в страны получателей таких «дешёвых» денег. Как нам видится, под видом спасения и помощи скрывается некая модель собственного экономического роста.

Если такое содействие и помощь носит периодический характер или вовсе постоянный, то это очень негативно может сказаться на социально-экономическом развитие получателей такой помощи, например, разрушение собственной сельскохозяйственной инфраструктуры, в результате чего косвенно создаются условия для обеднения населения и появления в будущем еще большего количества недоедающих людей. К тому же, как справедливо в свою очередь отмечает Ю.А. Валетова: «Нередко продовольственные поставки по программам помощи обогащают коррумпированных представителей местных властей и просто перепродаются по коммерческим ценам, то есть остаются недоступными для наиболее нуждающихся» [2].

Действуя в рамках Конвенции ООН об оказании продовольственной помощи 1999 года, вплоть до 2015 года, процент голодающих в мире постоянно сокращался. За это время в развивающихся странах доля тех, кому не хватает еды, снизилась с 35 до 15\%. ООН провозгласила великую цель - покончить с голодом на планете к 2030 г. Однако начиная с 2015 года, количество голодных начало расти и в 2019 году их стало на 60 млн. человек больше. В опубликованном в 2020 году ежегодном докладе UNICEF «Состояние продовольственной безопасности и питания в мире» говорится, что на 2019 год в мире насчитывалось 690 млн. голодающих. Кроме того, еще 3 млрд. человек просто не могут позволить себе здоровое питание [15].

Помимо таких негативных проявлений как глобальное потепление, вооруженные конфликты и в целом замедление роста мировой экономики, оказывающих влияние на рост числа голодающих, экспертами озвучивается еще не менее опасный союзник вышеперечисленных причин - пандемия COVID-19. Исполнительный директор Всемирной продовольственной программы ООН Дэвид Бизли предупредил об угрозе «голода библейских масштабов», который уже к концу года может свести на нет 30-летние достижения в борьбе с недоеданием. Согласно июльскому прогнозу, пандемия может заставить голодать еще 130 млн. человек. Но в случае неблагоприятного развития ситуации это число «может вырасти в разы» [15].

В завершении хотелось бы сказать, что факт колоссального рывка человечества в сфере IT - технологий, медицине и научно-технического прогресса в целом, никогда в полной мере не смогут заменить нам продовольствие, употребляемое человеком в пищу. Ни желание Илона Маска колонизировать планету Марс [16] ни представления Джеффа Безоса о создании плавучих космических городов цилиндрической формы, которые смогут вместить миллион человек и будет иметь свои «реки, леса и дикую природу» [17], не умоляют уникальность сельскохозяйственной отрасли на земле, ведь без преувеличения можно сказать, что правильно организованное и рационально используемое, развитое сельское хозяйство может являться основой благополучия не только отдельно взятой страны, но и всей планеты. 


\section{ЛИТЕРАТУРА}

1. Римская декларация о Всемирной продовольственной безопасности от 17 ноября 1996 года.

2. Диссертация к.ю.н., Валетова Ю.А. Международно-правовое обеспечение продовольственной безопасности. М.: 2013 г. стр. 30-60.

3. Диссертация д.ю.н., Ярандайкин Р.С. Организационно-правовые проблемы производства и реализации экологически чистой продукции. М.: 1999 г.

4. Декларация по окружающей среде и развитию от 14 июня 1992 г.

5. Рабцевич 0.И. Категория «Международное сообщество» и международное право//Современное право. Вып. № 9; 2016

6. Например: Договор о запрещении размещения на дне морей и океанов и в его недрах ядерного оружия и других видов оружия массового уничтожения 1971 г; Конвенция о запрещении разработки, производства и накопления запасов бактериологического (биологического) и токсинного оружия и $о б$ их уничтожении 1972 и ряд других международных документов.

7. Глобальная продовольственная безопасность: угрозы краткосрочного периода. Электронный ресурс: https://mgimo.ru/about/news/experts/ globalnaya-prodovolstvennaya bezopasnost-ugrozy-kratkosrochnogo-perioda/

8. Food and Agriculture Organization — Продовольственная и сельскохозяйственная организация 00H (FAO).

9. Интернет ресурс: фао.орг

10. United Nations Environmental Programme - главный орган 00Н, занимающийся вопросами охраны окружающей среды.

11. В последствии за несоблюдение отдельных статей Маастрихтского договора в 2006 году регламент был отменен Европейским судом. В январе 2008 года Комиссия ЕС и Европарламент решили, что определенный экспорт может максимум 12 месяцев иметь место быть до получения согласия от страны-импортера, если страна-экспортер не получила ответа от импортера в течение 2 месяцев. По запросу Европейского парламента это временное отступление применяется только к продуктам, зарегистрированным или разрешенным страной-импортером. Если продукт экспортируется из государства-члена в страну, не входящую в ОЭСР экспортирующее государство-член должно сначала принять во внимание возможные последствия для здоровья и или окружающей среды.

12. Правило XXXIII Общих правил Организации. Электронный ресурс: https://www.fao.org/unfao/govbodies/gsbhome/cfs/ru/

13. Диссертация к.ю.н., Литовченко А.С. Международно-правовые аспекты применения соглашения ВТ0 по сельскому хозяйству М.: 2005 г.

14. Конвенции об оказании продовольственной помощи 1999 г. (статья III) (с)

15. Электронный ресурс: https://www.vedomosti.ru/opinion/articles/2020/07/22/835100-kolichestvo-golodnih

16. Электронный ресурс: https://quote.rbc.ru/news/article/5ed13c549a79478838419124

17. Электронный ресурс: https://hi-tech.mail.ru/news/56161-rozhdennye-v-kosmose-zemlyanam-predskazali-udivitelnoe-buduschee/

( Амиров Дамир Камилевич ( Amirov@mail.ru ).

Журнал «Современная наука: актуальные проблемы теории и практики» 